Original research article

\title{
Fruit waste (peel) as bio-reductant to synthesize silver nanoparticles with antimicrobial, antioxidant and cytotoxic activities
}

\author{
Annu $^{a}$, Shakeel Ahmed ${ }^{\mathrm{a}, \mathrm{d}}$, Gurpreet Kaur ${ }^{\mathrm{b}, \mathrm{c}}$, Praveen Sharma ${ }^{\mathrm{c}}$, Sandeep Singh ${ }^{\mathrm{c}}$, \\ Saiqa Ikram $^{\mathrm{a}, *}$ \\ a Jamia Millia Islamia, Department of Chemistry, Bio/Polymers Research Laboratory, New Delhi, India \\ ${ }^{\mathrm{b}}$ Central University of Punjab, Centre for Environmental Science and Technology, Bathinda, India \\ ${ }^{\mathrm{c}}$ Central University of Punjab, Centre for Human Genetics and Molecular Medicine, Laboratory of Molecular Medicine, Bathinda, India \\ d Department of Chemistry, Government Degree College Mendhar, Jammu and Kashmir, India
}

\section{A R T I C L E I N F O}

\section{Article history:}

Received 21 March 2017

Received in revised form 8 December 2017

Accepted 5 February 2018

Available online 12 March 2018

\section{Keywords:}

Biosynthesis

Citrus fruits

Silver nanoparticles

Antimicrobial

Antioxidant

Anticancer

\section{A B S T R A C T}

Since last decade, biogenic synthesis of metal or metal-oxide nanoparticles is emerging as an alternative method, which is environment friendly, simple and safe to use. In this article, fruit waste (peel) extract (FWE) of three citrus fruits viz. Citrus limon, Citrus sinensis, and Citrus limetta were used as bio-reductant for green and sustainable synthesis of silver nanoparticles (AgNPs). As-synthesised AgNPs were characterized by using UV-vis spectroscopy, Dynamic light scattering, and High Resolution Transmission Electron Microscopy. TEM studies revealed 9-46 nm size range of synthesized AgNPs. The antimicrobial and antioxidant activities were also studied by using Agar well diffusion method and DPPH Assay, respectively. Nanoparticles showed good antimicrobial activity against both Gram positive (S. aureus) and Gram negative (E. coli) bacteria. Further, bioactivity assays revealed selective cytotoxicity (anticancer) of the nanoparticles against human lung cancer cell line A549. The nanoparticles are able to induce cancer cell specific apoptosis at G0/G1 phase of cell cycle. The results showed potential mechanism of action of nanoparticles via augmentation of antioxidant system in cancer cells. Over all, this study show multifaceted potential bioactivities of nanoparticles generated from fruit waste.

(c) 2018 Faculty of Health and Social Sciences, University of South Bohemia in Ceske Budejovice. Published by Elsevier Sp. z o.o. All rights reserved.

\section{Introduction}

Nowadays green chemistry is an emphasized area of research and require some additional efforts for the implementation of sustainable methods in order to achieve the desirable products as well as to minimize and further eliminate the waste materials produced (Anastas and Warner, 1998; Raveendran et al., 2003). Nanotechnology, an emerging field of research not only concise to materials instead include biological, medical and engineering also, hence introduced nanobiotechnology, a novel multidisciplinary approach which serves as domineering technique in developing and congregation of the nanoparticles via green methods for biomedical applications (Iravani et al., 2014). Nanoparticles have

\footnotetext{
* Author for correspondence: Jamia Millia Islamia, Department of Chemistry, Bio/ Polymers Research Laboratory, 110025 New Delhi, India.

E-mail addresses: shakeelchem11@gmail.com (S. Ahmed), sikram@jmi.ac.in (S. Ikram).
}

an ample of applications in various fields such as energy science, catalysis, light emitters, photo-electrochemical, single electron transistors, mechanics, optics, electronics, optoelectronics, nonlinear optical devices, space industries, chemical industries, biomedical sciences, drug delivery, tissue engineering, food, health care and cosmetics (Gupta and Gupta, 2005; Iravani et al., 2014; Scaramuzza et al., 2016; Wang and Herron, 1991). Among various nanoparticles such as Ag, Au, Ce, Pd, Pt and Zn, (Ahmed et al., 2016b, 2017a) AgNPs are well known for their constructive and beneficial inhibitory biomedical properties such as antibacterial (Sharma et al., 2009), antifungal (Panáček et al., 2009), antiviral (Trefry and Wooley, 2012), larvicidal activity, anti-inflammatory (David et al., 2014), and anti-angiogenesis (Baharara et al., 2014; Veerasamy et al., 2011) against different microbes, bacteria and fungi. Amid them, AgNPs also exhibits good catalytic activity with favourable thrombolytic as well as anticoagulant applications (Azeez et al., 2017b).

Conventionally, variable methods have been developed till date such as physical methods including thermal decomposition (Esumi 
et al., 1990), evaporation-condensation or laser ablation (Scaramuzza et al., 2016) and chemical methods involving reduction of solution to form metal clusters (Goia and Matijevic, 1998), photochemical reactions in reverse micelles (Taleb et al., 1997), sonochemical (Zhu et al., 2000), electrochemical (RodríguezSánchez et al., 2000), radiation assisted (Henglein, 1999, 2001) and recently via microwave assisted techniques (Chen et al., 2013). As these methods utilized precarious and environmentally lethal chemicals, required high energy, or low material conversions as well as tedious purification, hence arose different issues while going through these processes mainly regarding stabilization and aggregation of nanoparticles (Iravani et al., 2014). On the other hand, biogenic synthesis is an eco-friendly and sustainable one-pot synthesis route to synthesize the AgNPs. This method provides advancement over physical as well as chemical method as there is no need to use toxic chemicals, high energy, high temperature and pressure. Generally, plant leaf extract (Ahmed et al., 2016c), fruit peel extract (Bankar et al., 2010), microbes (Fariq et al., 2017; Hulkoti and Taranath, 2014), fungi (Anand et al., 2015) and enzymes (Liu et al., 2016) have been used as a source to synthesize nanoparticles. Furthermore, the agricultural wastes (Kumar et al., 2012), plant-derived pigments (Adelere and Lateef, 2016) and metabolites of arthropods (Lateef et al., 2016e) have also been used as a source of green synthesis of metallic nanoparticles.

This is due to the easy availability of plants, cost effectiveness, rapidity and proficient production. Recent literature revealed the enthusiasm of green route to synthesize AgNPs, for example, Azadirachta indica leaf extract (Ahmed et al., 2017b), Banana peel extract (Bankar et al., 2010), Mangosteen leaf (Veerasamy et al., 2011), Citrus sinensis peel (Kahrilas et al., 2014), Mangifera indica leaf (Philip, 2011), Terminalia arjuna leaf (Ahmed and Ikram, 2015), Murraya koenigii leaf (Philip et al., 2011), Punicia granatum peel (Ahmad et al., 2012), Cinnamomum zeylanicum leaf (Gauthami et al., 2015), and so on as given in Table 1.

As per green synthetic strategy, renewable as well as non-toxic materials should be used and we here too utilized a completely environmentally benign method in order to synthesize the AgNPs from the fruit waste i.e. peel, generated from Citrus fruits namely, Citrus limon (lemon), Citrus limetta (mosambi) and Citrus sinensis (orange). India ranks sixth in the production of citrus fruits and so as produce their waste materials i.e. peel. Citrus fruits are widely cultivated in tropical and subtropical regions in dried and arid condition. C. limetta is also known as sweet lime and in India it is popular as Mosambi, having a large number of benefits regarding health issues, like scurvy, peptic ulcer, diabetes, skin, hair, etc. Similarly, $C$. sinensis and $C$. limon have medicinal properties and hence found vast applications in various fields regarding health problems such as cancer, cormunative, stomach imbalance, diuretic and colic, bacterial infection and weak immunity besides cosmetics, skin and hair (Hussain et al., 2015; Nisha et al., 2014). Moreover, these citrus fruit waste have potent antimicrobial activity against Bacillus subtilis, Escherichia coli, Pseudomonas aeruginosa, Staphylococcus epidermidis, Staphylococcus aureus, Shigella flexineri, Candida parapsilosis and Candida albicans (Chabuck and Chabuck, 2014; Dubey et al., 2011; Panáček et al., 2009). Furthermore, antioxidant property of AgNPs from green methods have also been observed by many researchers and scientists mainly on leaf and flower extract (Aksoy et al., 2013; Phull et al., 2016). Cytotoxicity or cell viability of AgNPs have been observed by some researchers (Foldbjerg et al., 2011) but in this article, antioxidant and cytotoxicity was observed on blood cell as well as lung cancer cell line A549, of biologically synthesized AgNPs via a green and sustainable route from the waste materials produced, mainly for environmental concerns.

\section{Materials and methods}

Fresh lemons (Citrus limon), S1, oranges (Citrus sinensis), S2 and mosambi (Citrus limetta), S3 were procured from a local market in New Delhi, India. Silver nitrate was purchased from Merck Chemicals, Mumbai, India and was used as purchased. Mackonkey broth and Mackonkey Agar was purchased from HiMedia, Mumbai. Fresh blood around $5 \mathrm{ml}$ have been drawn from healthy individual as per the protocol number CUPB/cc/14/IEC/4483, Government of India. For blood cells, RPMI-1640 media having 5\% fetal calf serum (FCS), and RBC lysis buffer $(1 \times)$ were obtained from Invitrogen. CellROX ${ }^{\mathbb{R}}$ Deep Red from Invitrogen. All the cell lines were acquired from National Cell Repository, NCCS, Pune, India. For lung cancer cell line, A549, DMEM media augmented with $10 \%$ fetal bovine serum (FBS) and $1 \times$ antibiotic solution with $1 \%$ Pentsrip (50 U/ml penicillin G, $50 \mathrm{Ig} / \mathrm{ml}$ streptomycin sulfate and $1.25 \mathrm{lg} / \mathrm{ml}$ amphotericin B) were obtained from Invitrogen. DMSO solution, Dihydroethidium (DHE) and Butylhydroxytoluene (BHT) all were purchased from Sigma-Aldrich and used without further purification. All the glassware was washed thoroughly with chromic acid followed by distilled water and then transferred to oven for being dried before the experiment.

Table 1

Comparison of different source and their biosynthesized nanoparticles.

\begin{tabular}{|c|c|c|c|c|}
\hline Material required & Morphology & Size & Applications & References \\
\hline Leaf extract of Adiantum raddianum & $\begin{array}{l}\text { Spherical, Truncated triangles, and } \\
\text { Decahedron }\end{array}$ & $10.9 \mathrm{~nm}$ & $\begin{array}{l}\text { Toxicity against larvae of malaria and } \\
\text { filariasis vector }\end{array}$ & $\begin{array}{l}\text { Govindarajan et al. } \\
\text { (2017) }\end{array}$ \\
\hline Lactobacillus bacteria & Spherical & $30-100 \mathrm{~nm}$ & Antioxidant activity & Dakhil (2017) \\
\hline $\begin{array}{l}\text { Activated sludge micromycetes, } \\
\text { Fusarium nivale, }\end{array}$ & - & $\begin{array}{l}\text { more than } \\
100 \mathrm{~nm}\end{array}$ & Metal ion toxicity & Tyupa et al. (2016) \\
\hline $\begin{array}{l}\text { Fusarium oxysporum, Penicillium } \\
\quad \text { glabrum }\end{array}$ & & $\begin{array}{l}30-50 \mathrm{~nm} \\
20-30 \mathrm{~nm}\end{array}$ & & \\
\hline Bacillus safensis LAU 13 & - & $\sim 8.3 \mathrm{~nm}$ & - & Lateef et al. (2015) \\
\hline $\begin{array}{l}\text { Leaf and seed extracts of Synsepalum } \\
\text { dulcificum }\end{array}$ & Spherical & $4-26 \mathrm{~nm}$ & $\begin{array}{l}\text { Antimicrobial, catalytic, anticoagulant } \\
\text { and thrombolytic applications }\end{array}$ & Lateef et al. (2016a) \\
\hline Pod extract of Cola nitida & Spherical & $12-80 \mathrm{~nm}$ & $\begin{array}{l}\text { Antioxidant activity and phytochemical } \\
\text { contents of Amaranthus caudatus }\end{array}$ & Azeez et al. (2017a) \\
\hline Cocoa pod husk extract & Spherical & $4-32 \mathrm{~nm}$ & $\begin{array}{l}\text { Antimicrobial, antioxidant and larvicidal } \\
\text { activities }\end{array}$ & Lateef et al. (2016d) \\
\hline $\begin{array}{l}\text { Nest extract of paper wasp } \\
\quad \text { (Polistes sp.) }\end{array}$ & $\begin{array}{l}\text { Hexagonal, rhomboid, 3-D triangular, } \\
\text { rod and spherical }\end{array}$ & $12.5-95.55 \mathrm{~nm}$ & $\begin{array}{l}\text { Antimicrobial, catalytic, anticoagulating } \\
\text { and thrombolytic applications }\end{array}$ & Lateef et al. (2016b) \\
\hline $\begin{array}{l}\text { Cell-free extract of Bacillus safensis } \\
\text { LAU } 13\end{array}$ & Spherical & $5-95 \mathrm{~nm}$ & $\begin{array}{l}\text { Anti-candida, anti-coagulant and } \\
\text { thrombolytic activities }\end{array}$ & Lateef et al. (2016f) \\
\hline
\end{tabular}




\section{Biosynthesis of silver nanoparticles}

\section{Preparation of fruit waste (peel) extract (FWE)}

First of all, fruit waste (peel) of S1, S2 and S3 were washed with distilled water for removing the dust and debris and then again thoroughly washed with double distilled water. These peels were air dried and about $10 \mathrm{~g}$ each S1, S2 and S3 were weighed respectively. After that they were transferred to round bottom flask containing $250 \mathrm{ml}$ of double distilled water and then each were heated to boiled below $60^{\circ} \mathrm{C}$ for half an hour independently. Each FWE thus obtained were filtered using Whatman No. 1 filter paper and collected in glass media bottle to store in refrigerator for further experimental usage.

\section{Bio-reduction of AgNPs}

The source of silver for all experiments was aqueous silver nitrate. $250 \mathrm{ml} 4 \mathrm{mM}$ silver nitrate aqueous solution was prepared in an Erlenmeyer flask. Then $10 \mathrm{ml}$ of prepared silver nitrate was added to different concentrations of FWE in separate beakers further placed in dark chamber in order to minimize the photoreduction of silver nitrate solution at room temperature. In lieu of varying concentration of silver nitrate, the concentration of FWEs were varied and change in colour of solution was observed from colourless to yellowish to reddish brown and further characterized by UV-vis spectroscopy, Dynamic Light Scattering (DLS) and Transmission Electron Microscopy (TEM) of the respective samples and finally confirmed that these waste materials generated from fruits can also be used as advantageous candidate for bio-reduction of $\mathrm{Ag}^{+}$to $\mathrm{Ag}^{\mathrm{O}}$.

\section{Characterisation techniques}

\section{UV-vis spectroscopy}

UV-vis spectra were collected by using the instrument Shimadzu (UV-1800, Japan) at room temperature. The appropriate aqueous fruit peel extracts were taken as blank with same cuvette throughout the experiment with $1 \mathrm{~nm}$ resolution from 350 to 700 $\mathrm{nm}$ on the basis of literature available.

\section{Dynamic light scattering}

Recently this technique is also known as quasi-elastic light scattering. It has proven to be an invaluable analytical tool for characterising the size distribution of particles suspended in the solvent. The size of synthesized AgNPs were analysed by DLS with the help of instrument DLS Spectroscatter 201.

\section{Transmission electron microscopy}

The morphology of the surface as well as size of the synthesized nanosilver was confirmed by TEM using the instrument $300 \mathrm{kV}$ HRTEM TECHNAI G2 30S TWIN, operated at $3000 \mathrm{kV}$ accelerated voltage.

\section{Cytotoxicity analysis}

The cell toxicity was evaluated using MTT assay. The human peripheral blood mononucleated cells (hPBMN) were seeded in 96well culture plates and maintained in a RPMI-1640 medium supplemented with antibiotics and 5\% FCS (Fetal Calf Serum). Cells were treated with six different concentrations $(0.5,1,5,10$ and $50 \mu$ $\mathrm{g} / \mathrm{ml}$ ) for each S1, S2 and S3 with their respective extract E1, E2 and E3 (1, 0.2 and $10 \mu \mathrm{g} / \mathrm{ml}$ ) (Supplementary Fig. 1) and non-treated cells were used as control. Cell viability was evaluated under three time periods i.e. $24 \mathrm{~h}, 48 \mathrm{~h}$ and $72 \mathrm{~h}$ at $37^{\circ} \mathrm{C}$ with $5 \% \mathrm{CO}_{2}$. Then, $20 \mu$ lof MTT solution $(5 \mathrm{mg} / \mathrm{ml}$ ) were added to each well and incubated for $3 \mathrm{~h}$ in dark at $37^{\circ} \mathrm{C}$. Added $100 \mu \mathrm{l}$ DMSO and incubated for 30 min. The resultant formazan formed by viable cells were measured using a multi-mode plate reader at a wavelength of $570 \mathrm{~nm}$.
Antimicrobial assay

Prokaryotic bacteria, for example, E. coli and S. aureus were used as a source for examining antimicrobial activity using Agar well diffusion method. To subculture the bacteria, Mackonkey broth (HiMedia) as nutrient medium were prepared and incubated at $37^{\circ}$ $\mathrm{C}$ for $24 \mathrm{~h}$ and then it was kept for overnight. After that cultivation of bacteria was done by spreading fresh overnight cultures on Mackonkey nutrient agar plates. In each plate, double distilled water was used as control and $5 \mathrm{~mm}$ diameter hole was saturated with FWE and AgNPs and then again incubated at $37^{\circ} \mathrm{C}$ for $24 \mathrm{~h}$. Hence, on the basis of inhibition zone around the hole infused with both FWE and AgNPs antimicrobial activity were reported.

\section{Antioxidant activity of nanoparticles}

The DPPH free radical scavenging activity was evaluated using method of Marinova and Yanishlieva (1997) with few modifications. Three hundred microlitre of $200 \mu \mathrm{M}$ DPPH (in Methanol) was added to one hundred microliter S1, S2, S3 $(10 \mu \mathrm{g} / \mathrm{ml})$ and their respective extract $(10 \mu \mathrm{g} / \mathrm{ml})$ and BHT concentration (50 $\mathrm{mg} / \mathrm{ml}$ and $100 \mathrm{mg} / \mathrm{ml}$ ) as standard. After mixing, the mixture was incubated at temperature $37^{\circ} \mathrm{C}$ in dark environment for 30 min. Methanol $\left(\mathrm{CH}_{3} \mathrm{OH}\right)$ was used as blank for the appropriate absorbance with wavelength $517 \mathrm{~nm}$ using a multi-mode plate reader. The scavenging performance of free radicals was determined with the help of a formula as follows:

$\%$ Scavenging $=\frac{\text { Absorbance control }- \text { Absorbance of Test Sample }}{\text { Absorbance of Sample }}$

Intracellular ROS production using DHE staining

In order to evaluate the intracellular Reactive Oxygen Species (ROS), the dihydroethidium (DHE) stain (non-fluorescent) was used in A549 cells, seeded in 96-well plates at 1.0-1.2 $\times 10^{4}$ cells per well. The $\mathrm{H}_{2} \mathrm{O}_{2}$ treatment was used as positive control. The cultured cells were treated with S1, S2 and S3 (5 and $10 \mu \mathrm{g} / \mathrm{ml}$ ) and their respective extract $(10 \mu \mathrm{g} / \mathrm{ml})$ for $48 \mathrm{~h}$. Then, the DHE solution was added and incubated for $30 \mathrm{~min}$ at $37^{\circ} \mathrm{C}$ in absence of light which becomes fluorescent upon superoxide oxidation. The fluorescence with an excitation and emission wavelength of 518 $\mathrm{nm}$ and $605 \mathrm{~nm}$ respectively were measured with the help of a microplate reader.

Intracellular ROS production using CellROX ${ }^{\mathbb{R}}$ Deep Red staining

The generation of intracellular ROS was detected by using the fluorescent probe CellROX ${ }^{\circledR}$ Deep Red. The cells were treated with $\mathrm{S} 1, \mathrm{~S} 2, \mathrm{~S} 3$ and their extract $(10 \mu \mathrm{g} / \mathrm{ml})$ for $24 \mathrm{~h}$ and exposed to CellROX $^{\circledR}$ Deep Red ( $5 \mu \mathrm{M}$ for $30 \mathrm{~min}$ ) at $37^{\circ} \mathrm{C}$ under $5 \% \mathrm{CO}_{2}$ atmosphere in the dark. Furthermore, the fluorescence was measured at $633 \mathrm{~nm}$ and $665 \mathrm{~nm}$ excitation and emission wavelength respectively.

\section{Cell cycle analysis}

Cells were treated with S1 and S2 $(10 \mu \mathrm{g} / \mathrm{ml})$ and their respective extracts $(10 \mu \mathrm{g} / \mathrm{ml})$ for $24 \mathrm{~h}$ for cell cycle analysis and uniformly fixed in ice cold $70 \%$ ethanol for staining. About $200 \mu \mathrm{l}$ of ethanol-fixed cells processed according to Muse ${ }^{\mathrm{TM}}$ cell cycle analysis kit. Then, the cell suspension sample transferred to a micro centrifuge tube prior to analysis on Muse ${ }^{\mathrm{TM}}$ Cell Analyzer.

\section{Results and discussion}

Visual observation

On adding varying concentration of FWE to $10 \mathrm{ml}$ of $4 \mathrm{mM}$ silver nitrate solution, there is a colour change in the solution from colourless to yellowish and then to reddish brown after $30 \mathrm{~min}$ of 

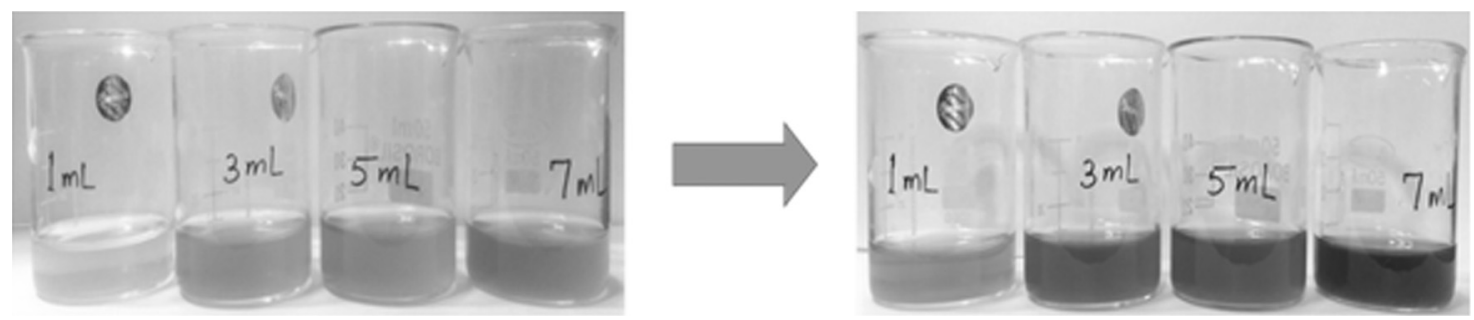

Fig. 1. Visual representation of biosynthesis of AgNPs with varying concentration of FWE.

addition, indicating the deepening of colour with increase in time (Fig. 1). This colour change inferred the formation of AgNPs, due to the excitation of surface plasmon vibrations. When the electrons of conduction band oscillate or vibrate collectively in resonance, then there exhibit a unique optical property known as Surface Plasmon Resonance (SPR) which in turn responsible for the absorption ranging between 400 and $500 \mathrm{~nm}$ in UV-vis spectra for the synthesized silver nanoparticles. Out of the citrus FWE engaged in the experiment, $C$. limon comparatively took more time in the formation of AgNPs. This method of using fruit waste as bioreductant is time saving with complete reduction of silver as reported in published literature (Lateef et al., 2016a; Kaviya et al., 2011; Prathna et al., 2011).

\section{UV-vis spectral studies}

The colour change inferred the formation of AgNPs and it was further confirmed by the UV-vis spectrophotometer. In order to determine the minimum time required for colour change, the experiment was performed at varying time interval and simultaneously their UV-vis spectral data were recorded. It was thus found that overall time required in synthesizing AgNPs were about $30 \mathrm{~min}$. for S2 and S3; and $1 \mathrm{~h}$ for S1 (Fig. 2). The concentration of aqueous solution of each of FWE was $1 \mathrm{ml}, 3 \mathrm{ml}, 5 \mathrm{ml}$ and $7 \mathrm{ml}$ keeping silver nitrate concentration constant. It was observed that the absorption wavelength of AgNPs for S1 were $448 \mathrm{~nm}, 440-450$ $\mathrm{nm}$ for S3 and $442-460 \mathrm{~nm}$ for S2. Lateef et al. (2016c) showed a)

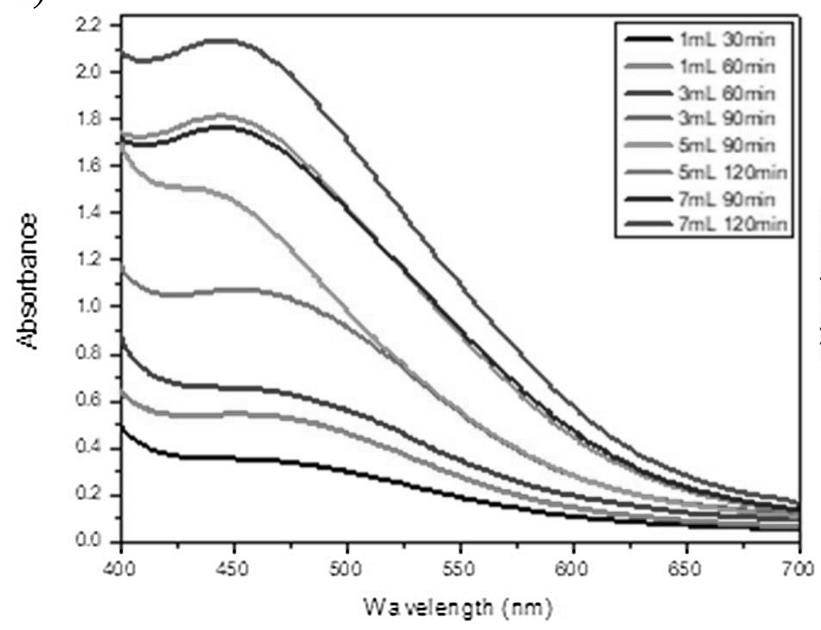

c)

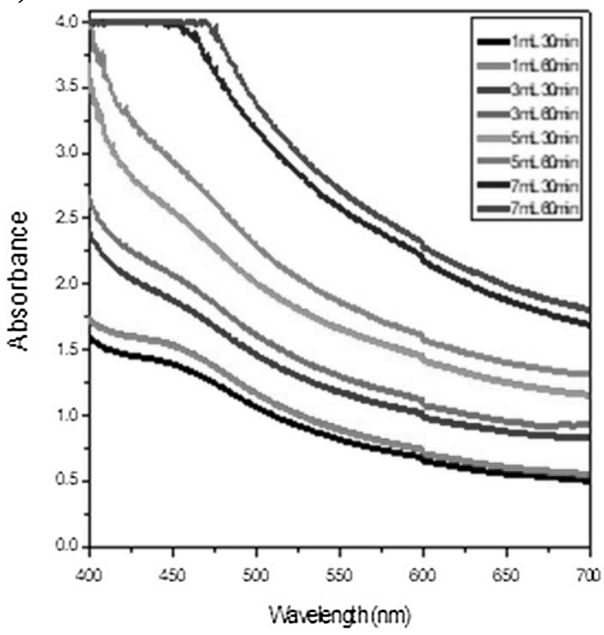

b)

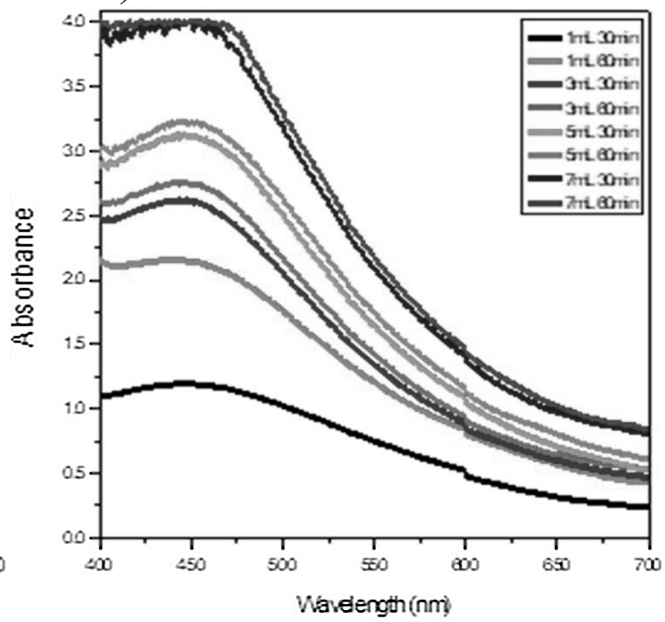

Fig. 2. UV-vis spectra of (a) S1, (b) S2 and (c) S3 at varying concentration of $1 \mathrm{ml}, 3 \mathrm{ml}, 5 \mathrm{ml}, 7 \mathrm{ml}$ in $4 \mathrm{mM}$ silver nitrate solution. 
$431.5 \mathrm{~nm}$ wavelength for Cola nitida synthesized AgNPs and hence in good agreement with our results A red shift in S2 has been observed on increasing the time interval of each concentration. This red shift was due to the holes injected to the clusters according to Henglein (1993) theory which deals with the actions of the plasmon shifts observed for bare clusters. Literature confirms many bio-organic compounds found in these citrus FWE such as $n$-octanal, perilla aldehyde, 2,6-dimethyl-2,6-octadiene-1, 8-dial, 4-isopropenyl-1-methyl-1,2-cyclohexanedial, limonene, $\beta$-linalool, $\alpha$-terpineol, geraniol, 1-octanol, $\beta$-linalool, 1-nonanol, 2-(4-methylenecyclohexyl)-2-propen-1-ol, perilla alcohol and 8-hydroxylinalool (Kahrilas et al., 2014). The concentration of each extract was optimized to $1 \mathrm{ml}$, and was used for further evaluation of AgNPs.

\section{Transmission electron microscopy (TEM)}

The shape and size of the nanoparticles were further evaluated and confirmed by using HRTEM analysis. The high resolution HRTEM studies revealed that the synthesized AgNPs of citrus FWE were spherical in shape and polydispersed and irregular. The measured size of these nanoparticles was in the range of 9-46 nm and the electron diffraction pattern has also been analysed as shown in Fig. 3. This data has been found in good agreement when compared with the reports available (Durand and Storz, 2017; Philip, 2011). For instance, Kaviya et al. (2011) showed $35 \pm 2 \mathrm{~nm}$ size range at room temperature and Lateef et al. (2016c) revealed size range of $12-80 \mathrm{~nm}$ of biologically synthesized AgNPs.

\section{Dynamic light scattering (DLS)}

The average size of AgNPs analyzed by DLS spectrometer was found to be $37.1 \mathrm{~nm}, 86.4 \mathrm{~nm}$ and $98.1 \mathrm{~nm}$ synthesised by S1, S2 and S3, respectively. The measured size of nanoparticles using DLS technique was large as compared to the TEM measurements. This is due to the fact that the water molecules present in the solution sample leads to increase the size of nanoparticles and this technique measured the hydrodynamic radius of the particle examined. The DLS histograms of the synthesized AgNPs from all the three FWE solution have been depicted in Fig. 4. Anandalakshmi et al. (2016) revealed similar results of particle size distribution in the range of $10-150 \mathrm{~nm}$ (average size $73.14 \mathrm{~nm}$ ) from the leaf extract of Pedalium murex.

\section{Antimicrobial assay}

Silver have been used in varying field of sciences and technology from ancient times and extend prestige from last ten
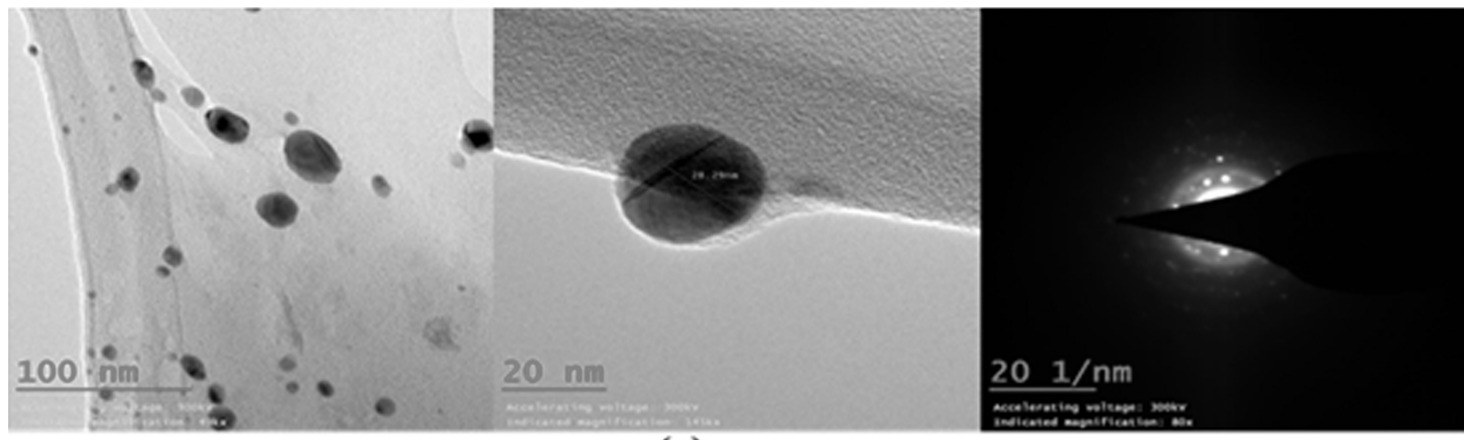

(a)
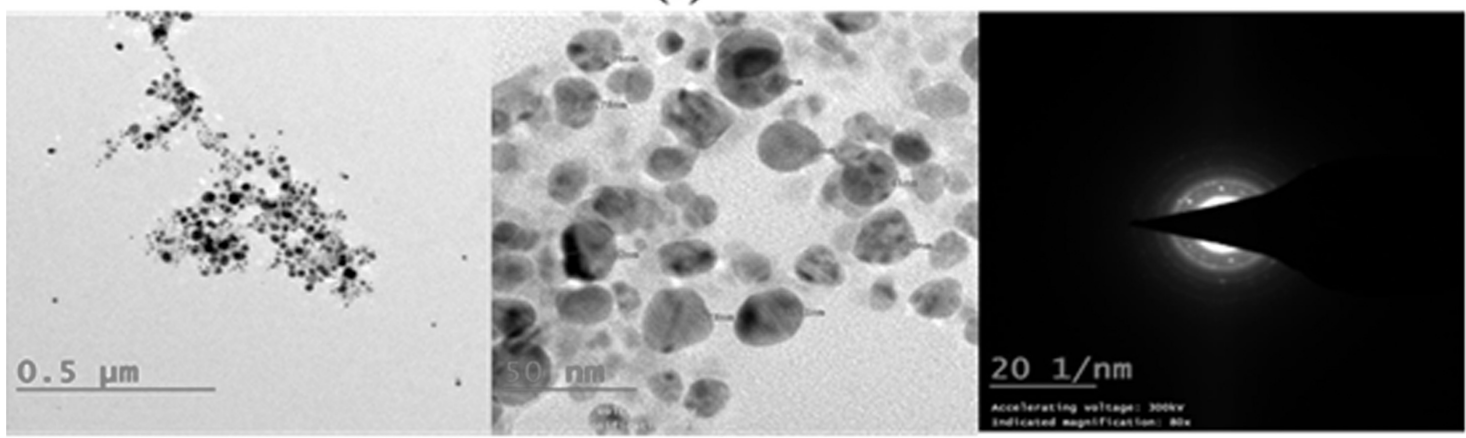

(b)
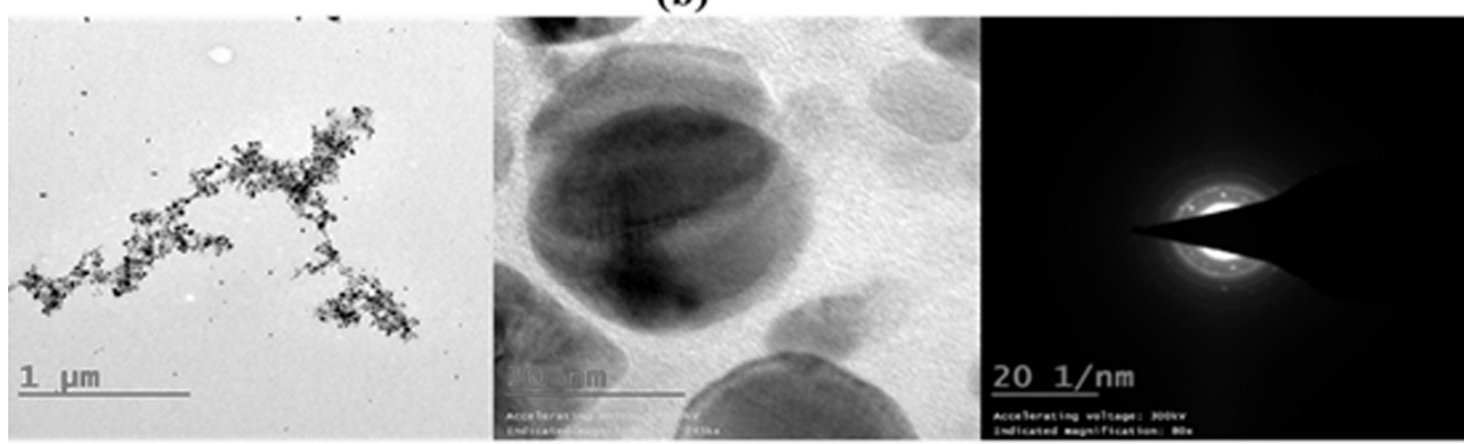

(c)

Fig. 3. TEM images of green mediated synthesized AgNPs from (a) S1, (b) S2 and (c) S3. 
a)

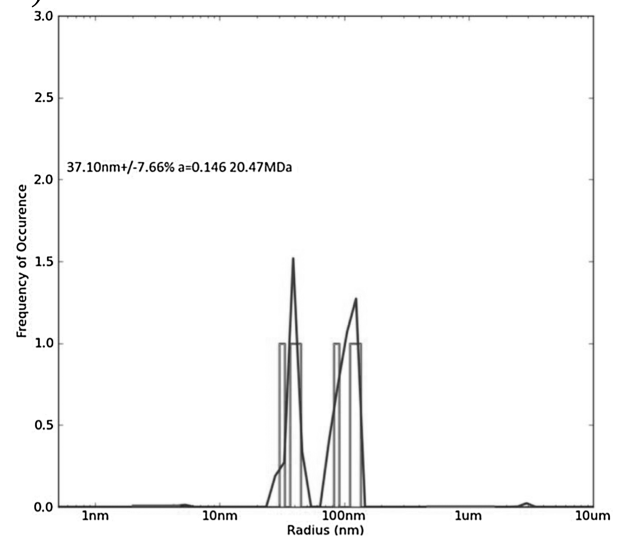

c)

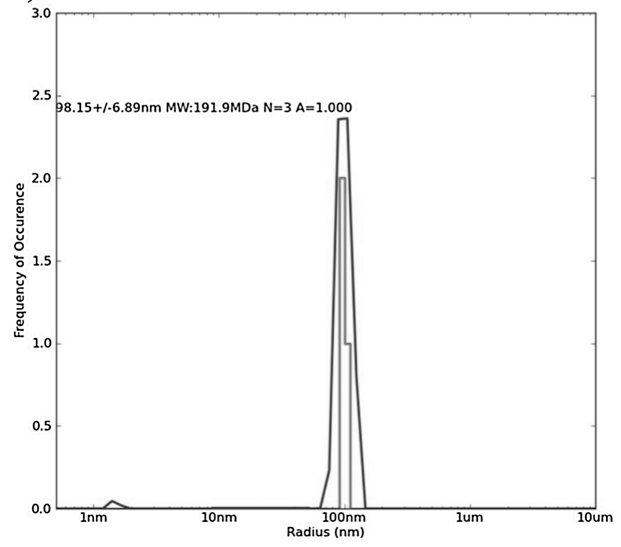

b)

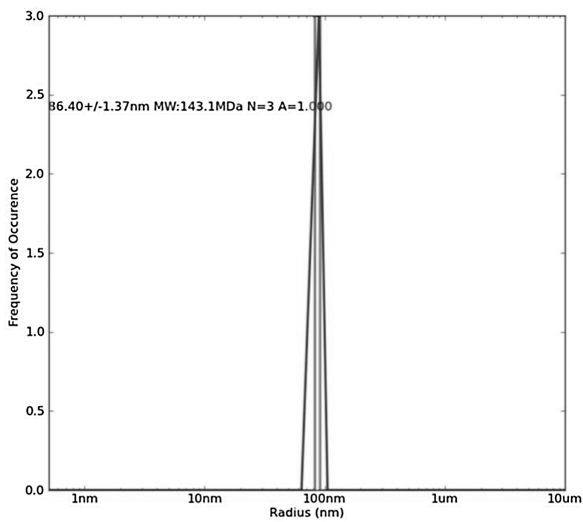

Fig. 4. DLS histograms of AgNPs of solution (a) C. limon (S1), (b) C. sinensis (S2) and (c) C. limetta (S3).

years due to its inherent antimicrobial property (Ahmed et al., 2016a). Generally, the inherent antimicrobial efficacy of green synthesized AgNPs were found to be dependent on the shapes and size of the nanoparticles and being confirmed by studying the zonal inhibition of bacterial growth by differentially shaped nanoparticles (Morones et al., 2005). As we have synthesized the AgNPs via green route so their antimicrobial assay was immediately done against both Gram positive, S. aureus as well as Gram negative, E. coli bacteria (Fig. 5 and Table 2) so as to show their efficacy by inhibition zone. In this study, each FWE and control independently, didn't possess any antimicrobial activity against these bacteria (Nisha et al., 2014). C. sinensis showed highest zone of inhibition of $28 \mathrm{~mm}$ against $S$. aureus whereas $C$. limetta showed $20 \mathrm{~mm}$ against $E$. coli. Lesser antibacterial activity of AgNPs is observed by C. limon for $20 \mu \mathrm{l} / \mathrm{ml}$. The study presented similar results as revealed in the literature available (Lateef et al., 2016c). The mechanism proposed for this can be described as: the extremely large surface area of AgNPs provide a better contact with the cell wall of the bacteria. Thus, the nanoparticle interacts with the DNA and S-containing proteins of the bacterial cell wall and finally penetrates into the cell creating a reservoir of low molecular weight region at the centre and attacks the mitochondria, cell division lead to death of the cell. Releasing of the $\mathrm{Ag}^{+}$ions in the bacterial cells enhanced the bactericidal activity (Ahmed et al., 2016a; Feng et al., 2000).

\section{Green nanoparticles with anti-cancer properties}

Cell viability was evaluated by doing MTT [3-(4, 5-dimethylthiazolyl)-2, 5-diphenyl-tetrazolium bromide] assay which involves the reduction of MTT by mitochondrial dehydrogenase to purple formazan in living cells. This reflects the functioning of mitochondria of viable cells, allowing the measurement of cell viability and cytotoxicity.

Reaction involved:

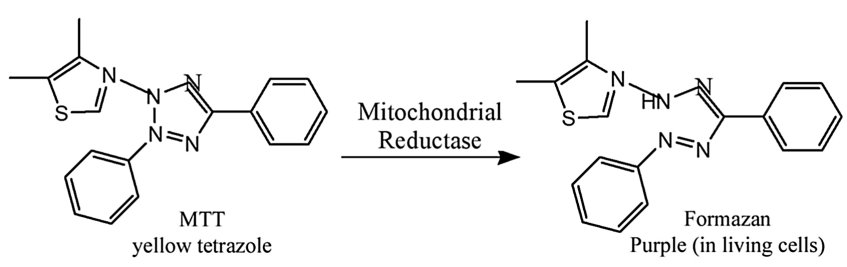

In this study, effect of silver nanoparticles were evaluated on the growth of these cells by MTT assay using A549 cancer cell lines at different concentrations $(0.5,1,5,10$ and $50 \mu \mathrm{g} / \mathrm{ml})$ and at three different time periods (24, 48 and $72 \mathrm{~h}$ ).

Our data revealed that all the samples showed very high anti proliferative activity at $50 \mu \mathrm{g} / \mathrm{ml}$ at all the three time points (Fig. 6A-C) while at $0.5 \mu \mathrm{g} / \mathrm{ml}$ approximately $20-30 \%$ inhibition at $72 \mathrm{~h}$ which was proven non-toxic at lower time points. Similarly, concentrations of 5 and $10 \mu \mathrm{g} / \mathrm{ml}$ also showed significant reduction in cell numbers at all the three time points. There were $50 \%$ of inhibition at concentrations $5 \mu \mathrm{g} / \mathrm{ml}$ and $10 \mu \mathrm{g} / \mathrm{ml}$ after $24 \mathrm{~h}$ of treatment with silver nanoparticle S1, whereas maximum inhibition (80\%) was observed at highest concentration of $50 \mu \mathrm{g} / \mathrm{ml}$ as shown in Fig. 6A. Growth inhibition 


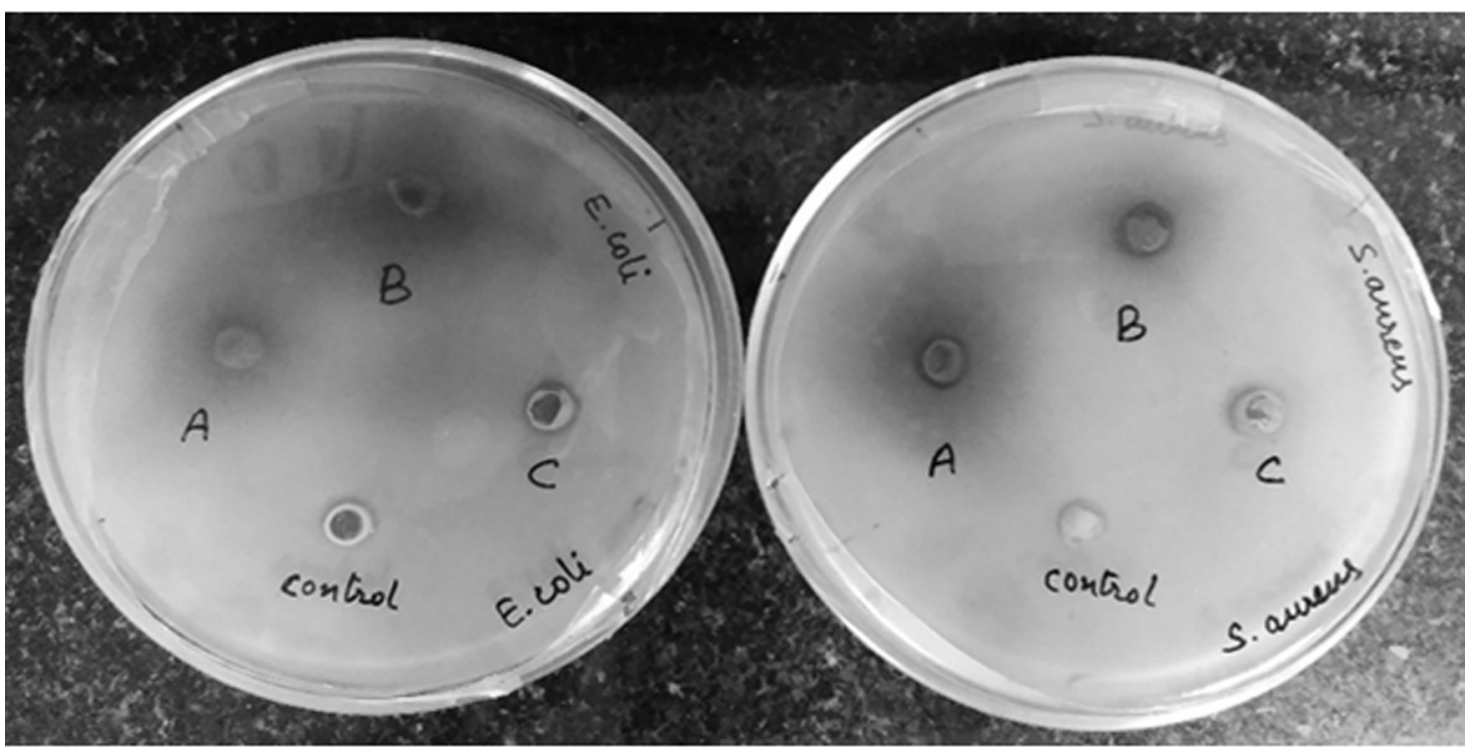

Fig. 5. Visual representation of antimicrobial activity shown by AgNPs against E. coli and S. aureus.

Table 2

Antimicrobial zone of inhibition ( $\mathrm{mm}$ ) obtained by Agar well diffusion method.

\begin{tabular}{cccc}
\hline & Sample & \multicolumn{2}{c}{ Zone of Inhibition (mm) } \\
\cline { 3 - 4 } & & E. coli & S. aureus \\
\hline 1. & Control & $\mathrm{NZ}$ & $\mathrm{NZ}$ \\
2. & Citrus sinensis & 17 & 28 \\
3. & Citrus limetta & 20 & 18 \\
4. & Citrus limon & 7 & 8 \\
\hline
\end{tabular}

$\mathrm{NZ}^{*}=$ No Zone of inhibition.

by silver nanoparticles S1 and S2 in $48 \mathrm{~h}$ were $20 \%$ and $30 \%$ respectively whereas $\mathrm{S} 3$ showed $50 \%$ of inhibition at $5 \mu \mathrm{g} / \mathrm{ml}$ as depicted in Fig. 6B. The S2 sample Exhibit $80 \%$ of inhibition at 10 $\mu \mathrm{g} / \mathrm{ml}$, whereas S1, S2 and S3 shows $90 \%$ growth inhibition at 50 $\mu \mathrm{g} / \mathrm{ml}$. After $72 \mathrm{~h}$ of treatment, S1, S2 and S3 $(5 \mu \mathrm{g} / \mathrm{ml})$ shows $60 \%, 46 \%$ and $41 \%$ respectively, but at $10 \mu \mathrm{g} / \mathrm{ml}$ there were about $61 \%, 75 \%$, and $52 \%$ of inhibition exerted by S1, S2, and S3, respectively as shown in Fig. 6C. The anti-proliferative potential of the pure extracts E1, E2 and E3 is shown in Supp. Fig. 1.

These results indicated that nanoparticles at lower concentration were also able to inhibit cancer cell growth in a time dependent fashion. Similar experiment was repeated for hPBMN cells as normal cell control. The results showed that there is a little or no toxicity of the nanoparticles at different concentrations and even at higher time points no toxicity were observed as depicted in Fig. 6D-F.

\section{AgNPs as potent antioxidant agents}

Several natural extract based anticancer potential was due to the presence of strong antioxidants in these extracts. Thus we decided to test the antioxidant potential of the extract coated silver nanoparticles using cell based as well as in vitro assays.

The in vitro free radical scavenging ability of nanoparticles was determined using DPPH free radical scavenging assay. In this study, DPPH tests demonstrated these nanoparticles as good free radical scavengers (Fig. 7). The 50 and $100 \mu \mathrm{g} / \mathrm{ml}$ concentration of BHT showed scavenging activity about $78.18 \%$ and $94.77 \%$ respectively when used as reference compound. On the other hand, S1, S2 and S3 showed 87.43\%, 67.50\%, and 95.13\% scavenging activity, respectively. So, these biologically synthesized nanoparticles exhibit potential to combat the free radicals generated as a result of oxidative stress. In this context, we further monitor the cellular antioxidant activity by inducing oxidative stress using $\mathrm{H}_{2} \mathrm{O}_{2}$ and pesticides. Antioxidant activity of AgNPs were similar to those found by Lateef et al. (2016c).

The intracellular ROS scavenging was measured by CellROX ${ }^{\mathrm{R}}$ Deep Red and DHE assay via inducing oxidative stress using $\mathrm{H}_{2} \mathrm{O}_{2}$ and pesticides. The cells were treated with respective nanoparticles as well as $\mathrm{H}_{2} \mathrm{O}_{2}$ pre-treatment (one hour) followed by nanoparticles ( $24 \mathrm{~h}$ ). Next day, the treated cells were exposed to DHE in absence of light to evaluate intracellular ROS in cell in response to the AgNPs. It was found that the non-florescent DHE easily permeates cell membranes that get oxidized by $\mathrm{O}^{2-}$ and converted to ethidium bromide (fluorescent) intercalates into nuclear DNA. The $\mathrm{H}_{2} \mathrm{O}_{2}$ treatment results in significant increase in the fluorescence intensity indicating higher intracellular ROS production (Fig. 8A). In contrast, both the concentration of $\mathrm{S} 1, \mathrm{~S} 2$ and S3 AgNPs $(0.5$ and $10 \mu \mathrm{g} / \mathrm{ml})$ demonstrated less intensity as compared to control. Interestingly, the fluorescence intensity decreases in cells treated with $\mathrm{H}_{2} \mathrm{O}_{2}$ followed with nanoparticles indicating that the AgNPs have potential to quench the induced reactive oxygen species. Similarly, the free radical scavenging activity was evaluated in response to oxidative stress induced using pesticide exposure and $\mathrm{H}_{2} \mathrm{O}_{2}$. It was found that the free radicals produced as a result of pesticides, were scavenged by the AgNPs treatment, that enter into the food chain as reported by many researchers (Gonzalez-Rodriguez et al., 2011; Popp et al., 2013). The intracellular ROS generation using fluorescent probe CellROX ${ }^{\mathbb{R}}$ Deep Red revealed similar results as obtained using DHE. The nanoparticles treatment decreased the oxidative stress induced due to $\mathrm{H}_{2} \mathrm{O}_{2}$ as well as pesticide treatment (Fig. 8B).

\section{AgNPs actively scavenge induced ROS in lung cancer cells}

The cell toxicity of AgNPs and extract on cancer cells as well as on the oxidative stress induced by $\mathrm{H}_{2} \mathrm{O}_{2}$ has been further studied. The cells were pre-treated with $\mathrm{H}_{2} \mathrm{O}_{2}$ followed by incubation with AgNPs. The results showed that $\mathrm{H}_{2} \mathrm{O}_{2}$ is able to increase ROS levels 

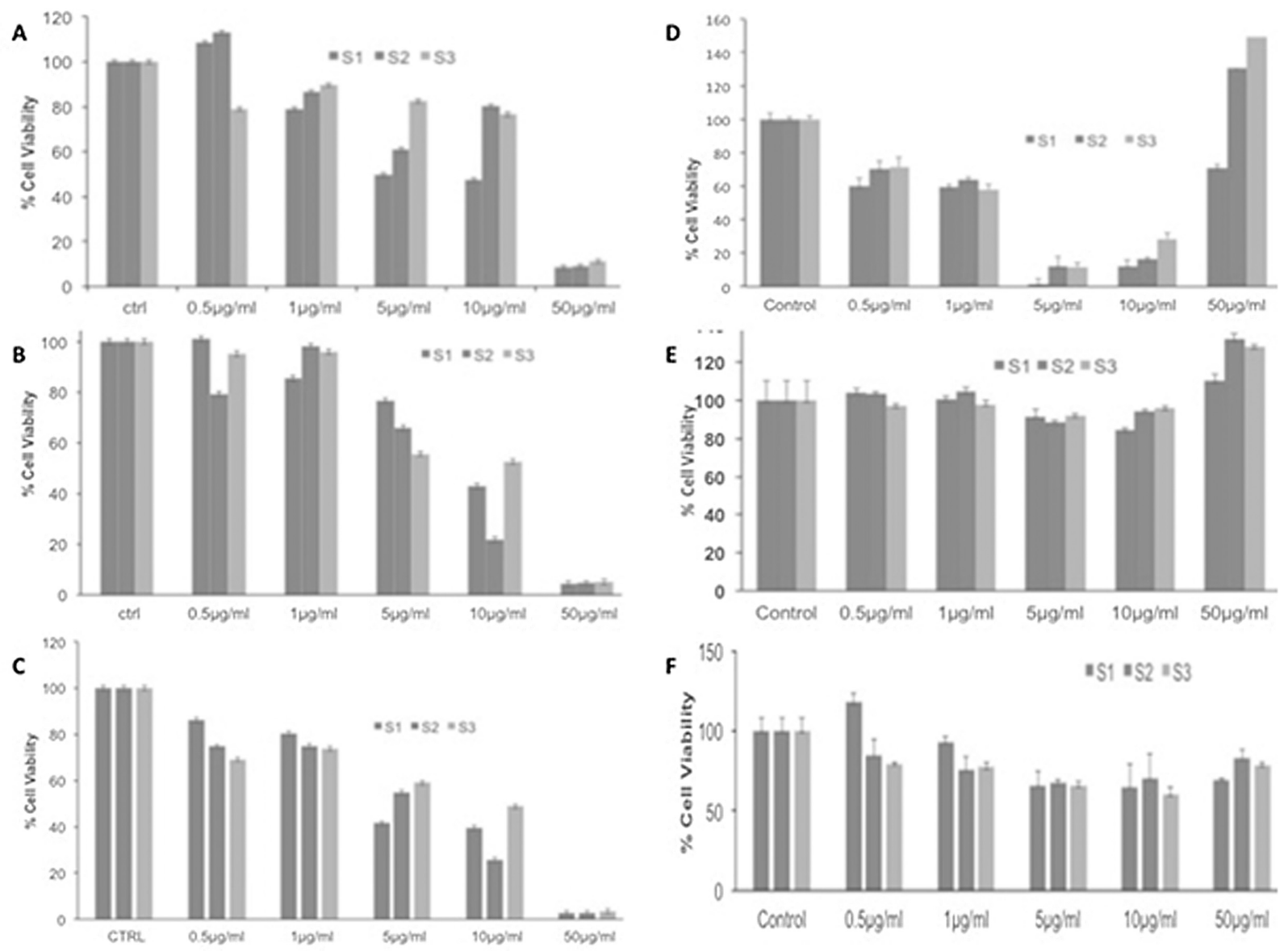

Fig. 6. Percent Cell viability upon treatment of S1, S2 and S3 green AgNPs on lung cancer cell lines A549 for (A) 24 h, (B) 48 h and (C) 72 h time points and on hPBMN for (D) 24 $\mathrm{h},(\mathrm{E}) 48 \mathrm{~h}$ and (F) $72 \mathrm{~h}$ time points.

by more than 2 folds, but in presence of AgNPs, the phenomenon is reversed and ROS levels remain closer to the control cell (Fig. 8A). Interestingly, all samples S1, S2 and S3 showed potent and active quenching of $\mathrm{H}_{2} \mathrm{O}_{2}$ induced ROS to compare its response with biologically synthesized AgNPs. The results revealed that $\mathrm{H}_{2} \mathrm{O}_{2}$ cause severe toxicity about $90.4 \%$ inhibition in cell viability, but only extract samples protect the cells from stress induced by $\mathrm{H}_{2} \mathrm{O}_{2}$ whereas the cell death observed with nanoparticle treatment in combination with $\mathrm{H}_{2} \mathrm{O}_{2}$ treatment. So, this suggests that extract quench the free radicals produced due to $\mathrm{H}_{2} \mathrm{O}_{2}$ and promote the cell survival (Supp. Fig. 2). Literature available also suggested higher reactive oxygen species in cancerous cell (Durand and Storz, 2017; Zhou et al., 2014).

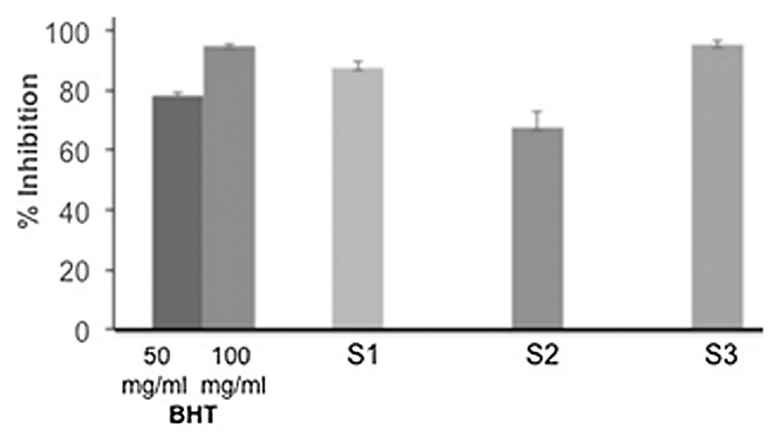

Fig. 7. Antioxidant activity of S1, S2, S3 nanoparticles using DPPH Assay.
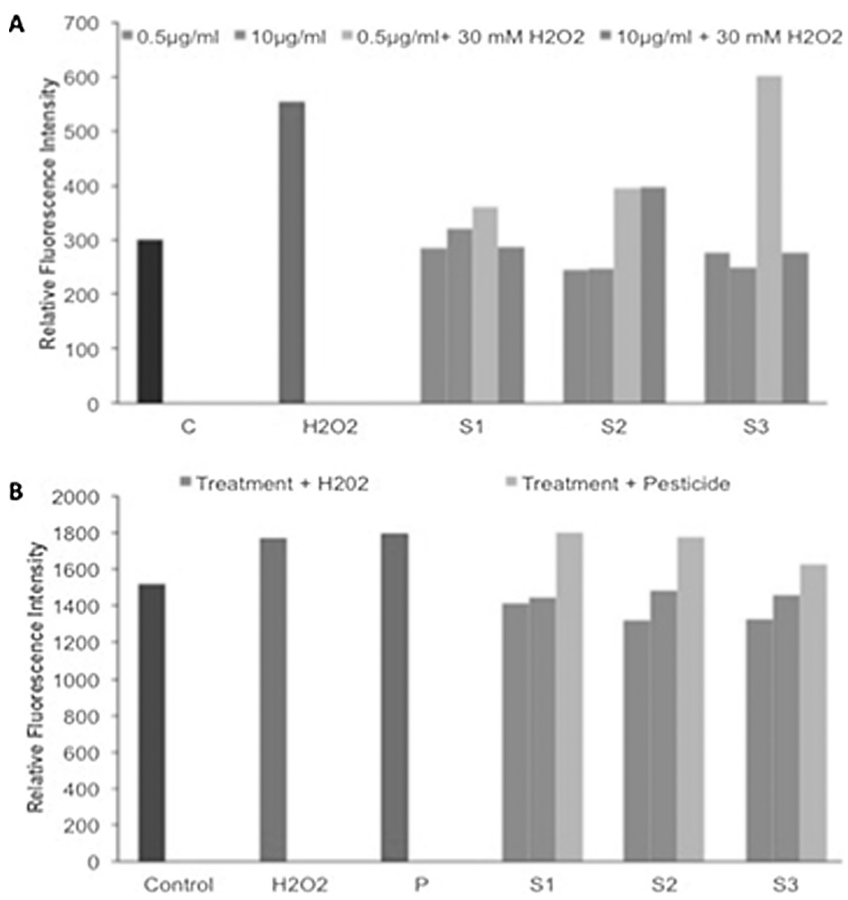

Fig. 8. (A) Intracellular ROS generation evaluation using DHE assay; (B) Intracellular ROS generation induced using $\mathrm{H}_{2} \mathrm{O}_{2}$ and Pesticide analysis using fluorescent probe CellROX ${ }^{\mathbb{R}}$ Deep Red. 
A

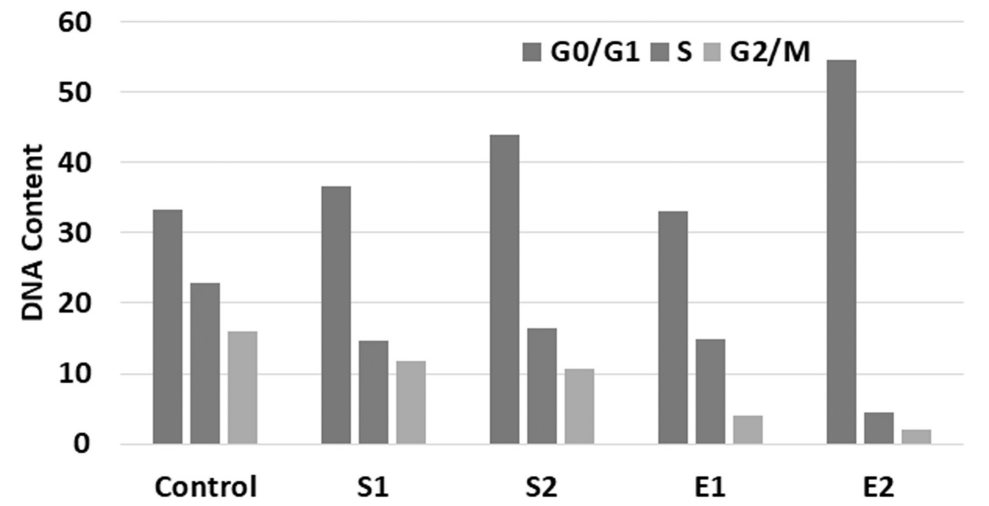

B

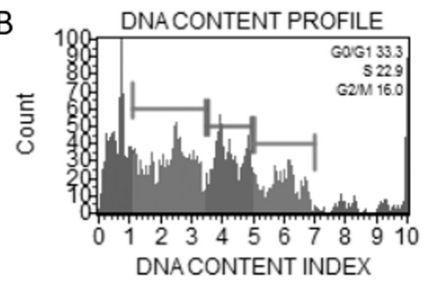

C

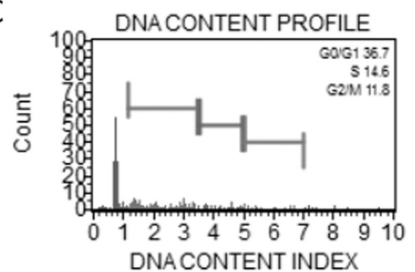

$\mathrm{F}$

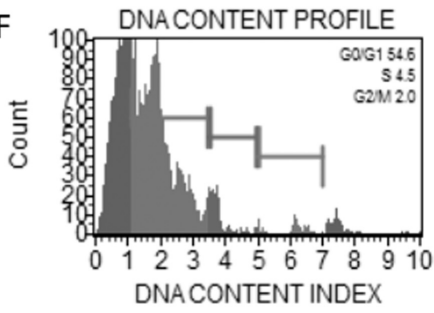

D

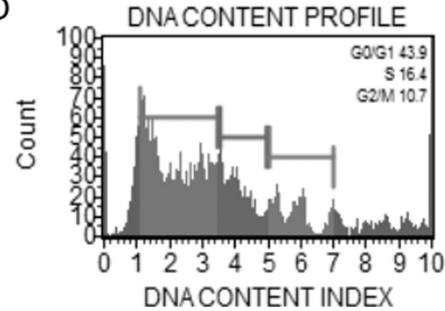

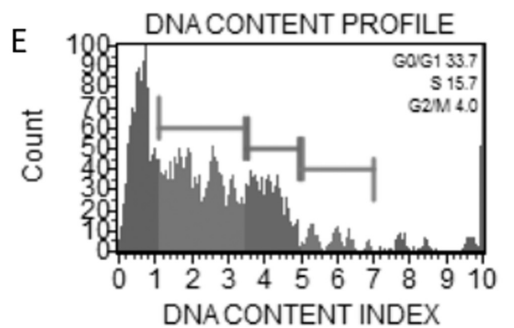

Fig. 9. (A) Effect of AgNPs and their respective extract on cell cycle; (B) DNA content profile of control; (C) S1; (D) E1 extract; (E) S2 sample; (F) E2 treated samples.

Green nanoparticles induced cell death by causing cell cycle arrest at G1 phase

Since cancer cell specific cytotoxicity by the nanoparticles was evaluated, thereafter the effect of AgNPs on cell cycle were observed. In this study, cells were treated with AgNPs followed by cell cycle analysis using MUSE cell analyzer (Merck-Millipore). Our results displayed peaks at G0/G1 (33.3\%), G2/M (16\%), S (22.9\%) phases for control sample. In contrast, the S1 nanoparticle treatment results increase in $10.21 \%$ G0/G1 peak values and decrease of 26.25\% G2/M whereas extract decreased S and G2/M phase about 34.5 and $75 \%$ respectively, (Fig. 9) with respect to control sample. On the other hand, the S2 and E2 treatment resulted increase of $31.83 \%$ and $63.96 \%$ of $\mathrm{G} 0 / \mathrm{G} 1$ phase respectively, whereas S and G2/M phase decrease about 28.38\% and 33.13\% (S2 treatment), $80.35 \%$ and $87.5 \%$ respectively (E2 treatment). The results of cell cycle analysis uncovered that A549 cells are arrested at the G0/G1 checkpoint with AgNPs treatment as compared to untreated cells. The prime reason for the cell cycle arrest was DNA damage and chromosomal aberrations as reported by AshaRani et al. (2009).

\section{Conclusion}

In this study, peels of three citrus fruits namely C. limon, $C$. limetta and $C$. sinensis have been used as waste material to successfully synthesize the AgNPs and accomplished under room temperature. We have demonstrated the cost effective, time saving, renewable, green and sustainable route for AgNPs to be formed. The FWE itself acts as bio-reductant, stabilising as well as capping agent. The confirmation for the formation of nanoparticles were observed by colour change and UV-vis spectra obtained and further the size and shape determination has been done by DLS and HR-TEM. The size of the synthesized spherical AgNPs were found to be in the range of 9 to $46 \mathrm{~nm}$. These nanoparticles showed respectable antimicrobial activity against $E$. coli and S. aureus $(20 \mu \mathrm{l} / \mathrm{ml})$. Moreover, DPPH assay revealed potent antioxidant activity of these AgNPs. Besides, cause apoptosis by cell cycle arrest at G1 phase and hence these biogenically AgNPs are found to be quite safe for normal human cells when tested in vitro. Overall, the study showed that the nanoparticles which we synthesized from the waste material (peel) of the citrus fruits not only exhibit the antimicrobial activity but also possess beneficial antioxidant and anticancer activity as well. This may open a new avenue of anticancer therapies which requires further exploration.

\section{Author's contributions}

Annu and SA have biologically synthesised and characterized AgNPs. SS and SI have designed all the biological experiments. GK and PS have performed various biological assays in primary cells as well as cancer cell lines.

\section{Conflict of interests}

The authors declare no conflict of interests.

\section{Acknowledgements}

Annu appreciatively acknowledges the University Grant Commission (UGC), New Delhi, India for the financial support. Gurpreet Kaur is recipient of Maulana Azad National Fellowship. Praveen Sharma and Sandeep Singh are thankful to DST for SERB extra mural project (SR/SO/AS-31/2014).

\section{Appendix A. Supplementary data}

Supplementary data associated with this article can be found, in the online version, at https://doi.org/10.1016/j.jab.2018.02.002. 


\section{References}

Adelere, I., Lateef, A., 2016. A novel approach to the green synthesis of metallic nanoparticles: the use of agro-wastes, enzymes, and pigments. Nanotechnol. Rev. 5 (6), 567-587.

Ahmad, N., Sharma, S., Rai, R., 2012. Rapid green synthesis of silver and gold nanoparticles using peels of Punica granatum. Adv. Mater. Lett. 3 (5), 1-13. doi http://dx.doi.org/10.5185/amlett.2012.5357.

Ahmed, S., Ikram, S., 2015. Silver nanoparticles: one pot green synthesis using Terminalia arjuna extract for biological application. J. Nanomed. Nanotechnol. $6,4$.

Ahmed, S., Ahmad, M., Swami, B.L., Ikram, S., 2016a. A review on plants extract mediated synthesis of silver nanoparticles for antimicrobial applications: a green expertise. J. Adv. Res. 7, 17-28.

Ahmed, S., Annu Ikram, S., Yudha, S.S., 2016b. Biosynthesis of gold nanoparticles: a green approach. J. Photochem. Photobiol. 161, 141-153.

Ahmed, S., Annu Zafeer, I., Ikram, S., 2016c. One-step method for formation of silver nanoparticles using withania somnifera extract for antimicrobial activities. J. Bionanosci. 10, 1-7.

Ahmed, S., Annu Ali, S., Ikram, S., 2017a. A review on biogenic synthesis of ZnO nanoparticles using plant extracts and microbes: a prospect towards green chemistry. J. Photochem. Photobiol. 166, 272-284.

Ahmed, S., Saifullah, Ahmad, M., Swami, B.L., Ikram, S., 2017b. Green synthesis of silver nanoparticles using Azadirachta indica aqueous leaf extract. J. Radiat. Res. Appl. Sci. 9 (1), 1-7.

Aksoy, L., Kolay, E., Ağılönü, Y., Aslan, Z., Kargığlu, M., 2013. Free radical scavenging activity, total phenolic content, total antioxidant status, and total oxidant status of endemic Thermopsis turcica. Saudi J. Biol. Sci. 20, 235-239.

Anand, B.G., Thomas, C.K.N., Prakash, S., Kumar, C.S., 2015. Biosynthesis of silver nano-particles by marine sediment fungi for a dose dependent cytotoxicity against \{HEp2\} cell lines. Biocatal. Agric. Biotechnol. 4, 150-157.

Anandalakshmi, K., Venugobal, J., Ramasamy, V., 2016. Characterization of silver nanoparticles by green synthesis method using Pedalium murex leaf extract and their antibacterial activity. Appl. Nanosci. 6, 399-408.

Anastas, P.T., Warner, J.C., 1998. Green Chemistry: Theory and Practice. Oxford University Press, New York.

AshaRani, P.V., Kah, Low, Mun, G., Hande, M.P., Valiyaveettil, S., 2009. Cytotoxicity and genotoxicity of silver nanoparticles in human cells. ACS Nano 3, 279-290.

Azeez, L., Lateef, A., Adebisi, S.A., 2017a. Silver nanoparticles (AgNPs) biosynthesized using pod extract of Cola nitida enhances antioxidant activity and phytochemical composition of Amaranthus caudatus Linn. Appl. Nanosci. 7, 5966.

Azeez, M.A., Lateef, A., Asafa, T.B., Yekeen, T.A., Akinboro, A., Oladipo, I.C., et al., 2017b. Biomedical applications of cocoa bean extract-mediated silver nanoparticles as antimicrobial, larvicidal and anticoagulant agents. J. Clust. Sci. $28,149-164$.

Baharara, J., Namvar, F., Mousavi, M., Ramezani, T., Mohamad, R., 2014. Antiangiogenesis effect of biogenic silver nanoparticles synthesized using Saliva officinalis on chick chorioalantoic membrane (CAM). Molecules 19, 1349813508.

Bankar, A., Joshi, B., Kumar, A.R., Zinjarde, S., 2010. Banana peel extract mediated novel route for the synthesis of silver nanoparticles. Colloids Surf. A Physicochem. Eng. Asp. 368, 58-63.

Chabuck, S.I.A., Chabuck, N.A.G., 2014. In vitro and in vivo effect of three aqueous plant extract on pathogenicity of Klebsiella pneumonia isolated from patient with urinary tract infection. World J. Pharm. Res. 3, 160-179.

Chen, D., Zhang, Y., Chen, B., Kang, Z., 2013. Coupling effect of microwave and mechanical forces during the synthesis of ferrite nanoparticles by microwaveassisted ball milling. Ind. Eng. Chem. Res. 52, 14179-14184. doi:http://dx.doi. org/10.1021/ie401890j.

Dakhil, A.S., 2017. Biosynthesis of silver nanoparticle (AgNPs) using Lactobacillus and their effects on oxidative stress biomarkers in rats. J. King Saud Univ.-Sci. 29 (4), $462-467$.

David, L., Moldovan, B., Vulcu, A., Olenic, L., Perde-Schrepler, M., Fischer-Fodor, E., et al., 2014. Green synthesis, characterization and anti-inflammatory activity of silver nanoparticles using European black elderberry fruits extract. Colloids Surf. B Biointerfaces 122, 767-777.

Dubey, D., Balamurugan, K., Agrawal, R.C., Verma, R., Jain, R., 2011. Evaluation of antibacterial and antioxidant activity of methanolic and hydromethanolic extract of sweet orange peels. Recent Res. Sci. Technol. 3, 22-25.

Durand, N., Storz, P., 2017. Targeting reactive oxygen species in development and progression of pancreatic cancer. Expert Rev. Anticancer Ther. 17 (1), 19-31.

Esumi, K., Tano, T., Torigoe, K., Meguro, K., 1990. Preparation and characterization of bimetallic Pd-Cu colloids by thermal decomposition of their acetate compounds in organic solvents. Chem. Mater. 2, 564-567.

Fariq, A., Khan, T., Yasmin, A., 2017. Microbial synthesis of nanoparticles and their potential applications in biomedicine. J. Appl. Biomed. 15, 241-248.

Feng, Q.L., Wu, J., Chen, G.Q., Cui, F.Z., Kim, T.N., Kim, J.O., 2000. A mechanistic study of the antibacterial effect of silver ions on Escherichia coli and Staphylococcus aureus. J. Biomed. Mater. Res. 52, 662-668.

Foldbjerg, R., Anh, D., Herman, D., 2011. Cytotoxicity and genotoxicity of silver nanoparticles in the human lung cancer cell line, A549. Arch. Toxicol. 743-750.

Gauthami, M., Srinivasan, N., Goud, N.M., Boopalan, K., Thirumurugan, K., 2015. Synthesis of silver nanoparticles using Cinnamomum zeylanicum bark extract and its antioxidant activity. Nanosci. Nanotechnol.-ASIA 5 (1), 2-7.
Goia, D.V., Matijevic, E., 1998. Preparation of monodispersed metal particles. New J. Chem. 22 (11), 1203-1215

Gonzalez-Rodriguez, R.M., Rial-Otero, R., Cancho-Grande, B., Gonzalez-Barreiro, C. Simal-Gandara, J., 2011. A review on the fate of pesticides during the processes within the food-production chain. Crit. Rev. Food Sci. Nutr. 51, 99-114.

Govindarajan, M., AlQahtani, F.S., AlShebly, M.M., Benelli, G., 2017. One-pot and ecofriendly synthesis of silver nanocrystals using Adiantum raddianum: toxicity against mosquito vectors of medical and veterinary importance. J. Appl. Biomed. $15,87-95$.

Gupta, A.K., Gupta, M., 2005. Synthesis and surface engineering of iron oxide nanoparticles for biomedical applications. Biomaterials 26, 3995-4021.

Henglein, A., 1993. Physicochemical properties of small metal particles in solution: microelectrode reactions, chemisorption, composite metal particles, and the atom-to-metal transition. J. Phys. Chem. 97, 5457-5471.

Henglein, A., 1999. Radiolytic preparation of ultrafine colloidal gold particles in aqueous solution:optical spectrum, controlled growth, and some chemical reactions. Langmuir $15,6738-6744$.

Henglein, A., 2001. Reduction of $\mathrm{Ag}(\mathrm{CN}) 2$ - on silver and platinum colloidal nanoparticles. Langmuir 17, 2329-2333.

Hulkoti, N.I., Taranath, T.C., 2014. Biosynthesis of nanoparticles using microbes-a review. Colloids Surf. B Biointerfaces 121, 474-483.

Hussain, K.A., Tarakji, B., Kandy, B.P.P., John, J., Mathews, J., Ramphul, V., Divakar, D.D., 2015. Antimicrobial effects of citrus sinensis peel extracts against periodontopathic bacteria: an in vitro study. Rocz. Państwowego Zakładu Hig. 66, 173-178.

Iravani, S., Korbekandi, H., Mirmohammadi, S.V., Zolfaghari, B., 2014. Synthesis of silver nanoparticles: chemical, physical and biological methods. Res. Pharm. Sci. 9 (6), 385-406.

Kahrilas, G.A., Wally, L.M., Fredrick, S.J., Hiskey, M., Prieto, A.L., Owens, J.E., 2014. Microwave-assisted green synthesis of silver nanoparticles using orange peel extract. ACS Sustain. Chem. Eng. 2, 367-376.

Kaviya, S., Santhanalakshmi, J., Viswanathan, B., Muthumary, J., Srinivasan, K., 2011. Biosynthesis of silver nanoparticles using citrus sinensis peel extract and its antibacterial activity. Spectrochim. Acta Part A Mol. Biomol. Spectrosc. 79, 594598.

Kumar, R., Roopan, S.M., Prabhakarn, A., Khanna, V.G., Chakroborty, S., 2012. Agricultural waste Annona squamosa peel extract: biosynthesis of silver nanoparticles. Spectrochim. Acta Part A Mol. Biomol. Spectrosc. 90, 173-176.

Lateef, A., Adelere, I.A., Gueguim-Kana, E.B., Asafa, T.B., Beukes, L.S., 2015. Green synthesis of silver nanoparticles using keratinase obtained from a strain of Bacillus safensis LAU 13. Int. Nano Lett. 5, 29-35.

Lateef, A., Akande, M.A., Azeez, M.A., Ojo, S.A., Folarin, B.I., Gueguim-Kana, E.B., Beukes, L.S., 2016a. Phytosynthesis of silver nanoparticles (AgNPs) using miracle fruit plant (Synsepalum dulcificum) for antimicrobial, catalytic, anticoagulant, and thrombolytic applications. Nanotechnol. Rev. 5 (6), 507-520.

Lateef, A., Akande, M.A., Ojo, S.A., Folarin, B.I., Gueguim-Kana, E.B., Beukes, L.S., 2016b. Paper wasp nest-mediated biosynthesis of silver nanoparticles for antimicrobial, catalytic, anticoagulant, and thrombolytic applications. 3 Biotech. 6 (2), 140.

Lateef, A., Azeez, M.A., Asafa, T.B., Yekeen, T.A., Akinboro, A., Oladipo, I.C., et al. 2016c. Biogenic synthesis of silver nanoparticles using a pod extract of Cola nitida: antibacterial and antioxidant activities and application as a paint additive. J. Taibah Univ. Sci. 10, 551-562.

Lateef, A., Azeez, M.A., Asafa, T.B., Yekeen, T.A., Akinboro, A., Oladipo, I.C., et al., 2016d. Cocoa pod husk extract-mediated biosynthesis of silver nanoparticles: its antimicrobial, antioxidant and larvicidal activities. J. Nanostruct. Chem. 6, 159-169.

Lateef, A., Ojo, S.A., Elegbede, J.A., 2016e. The emerging roles of arthropods and their metabolites in the green synthesis of metallic nanoparticles. Nanotechnol. Rev. 5, 601-622.

Lateef, A., Ojo, S.A., Oladejo, S.M., 2016f. Anti-candida, anti-coagulant and thrombolytic activities of biosynthesized silver nanoparticles using cell-free extract of Bacillus safensis LAU 13. Process Biochem. 51, 1406-1412.

Liu, S., Wei, W., Wang, Y., Fang, L., Wang, L., Li, F., 2016. Ultrasensitive electrochemical detection of nucleic acid by coupling an autonomous cascade target replication and enzyme/gold nanoparticle-based post-amplification. Biosens. Bioelectron. 80, 208-214.

Marinova, E.M., Yanishlieva, N.V., 1997. Antioxidative activity of extracts from selected species of the family Lamiaceae in sunflower oil. Food Chem. 58, 245248.

Morones, J.R., Elechiguerra, J.L., Camacho, A., Holt, K., Kouri, J.B., Ramirez, J.T., Yacaman, M.J., 2005. The bactericidal effect of silver nanoparticles. Nanotechnology 16, 2346-2353.

Nisha, S.N., Aysha, O.S., Nasar, J.S., Kumar, P.V., Valli, S., Nirmala, P., Reena, A., 2014 Lemon peels mediated synthesis of silver nanoparticles and its antidermatophytic activity. Spectrochim. Acta Part A Mol. Biomol. Spectrosc 124, 194-198.

Panáček, A., Kolář, M., Večeřová, R., Prucek, R., Soukupová, J., Kryštof, V., et al., 2009. Antifungal activity of silver nanoparticles against Candida spp. Biomaterials 30, 6333-6340.

Philip, D., Unni, C., Aromal, S.A., Vidhu, V.K., 2011. Murraya koenigii leaf-assisted rapid green synthesis of silver and gold nanoparticles. Spectrochim. Acta Part A Mol. Biomol. Spectrosc. 78, 899-904.

Philip, D., 2011. Mangifera indica leaf-assisted biosynthesis of well-dispersed silver nanoparticles. Spectrochim. Acta Part A Mol. Biomol. Spectrosc. 78 (1), 327-331. 
Phull, A.-R., Abbas, Q., Ali, A., Raza, H., Kim, S.J., Zia, M., Haq, I., 2016. Antioxidant, cytotoxic and antimicrobial activities of green synthesized silver nanoparticles from crude extract of Bergenia ciliata. Futur. J. Pharm. Sci. 2, 31-36.

Popp, J., Pet-Ho, K., Nagy, J., 2013. Pesticide productivity and food security-a review. Agron. Sustain. Dev. 33, 243-255.

Prathna, T.C., Chandrasekaran, N., Raichur, A.M., Mukherjee, A., 2011. Biomimetic synthesis of silver nanoparticles by Citrus limon (lemon) aqueous extract and theoretical prediction of particle size. Colloids Surf. B Biointerfaces 82,152-159.

Raveendran, P., Fu, J., Wallen, S.L., Hill, C., Carolina, N., 2003. Completely green synthesis and stabilization of metal nanoparticles. J. Am. Chem. Soc. 13940 13941.

Rodríguez-Sánchez, L., Blanco, M.C., López-Quintela, M.A., 2000. Electrochemical synthesis of silver nanoparticles. J. Phys. Chem. B 104, 9683-9688.

Scaramuzza, S., Zerbetto, M., Amendola, V., 2016. Synthesis of gold nanoparticles in liquid environment by laser ablation with geometrically confined configurations: insights to improve size control and productivity. J. Phys. Chem. C $120,9453-9463$.

Sharma, V.K., Yngard, R.A., Lin, Y., 2009. Silver nanoparticles: green synthesis and their antimicrobial activities. Adv. Colloid Interface Sci. 145, 83-96.

Taleb, A., Petit, C., Pileni, M.P., 1997. Synthesis of highly monodisperse silver nanoparticles from AOT reverse micelles:a way to 2D and 3D self-organization. Chem. Mater. 9, 950-959.
Trefry, J.C., Wooley, D.P., 2012. Rapid assessment of antiviral activity and cytotoxicity of silver nanoparticles using a novel application of the tetrazolium-based colorimetric assay. J. Virol. Methods 183, 19-24.

Tyupa, D.V., Kalenov, S.V., Baurina, M.M., Yakubovich, L.M., Morozov, A.N., Zakalyukin, R.M., et al., 2016. Efficient continuous biosynthesis of silver nanoparticles by activated sludge micromycetes with enhanced tolerance to metal ion toxicity. Enzyme Microb. Technol. 95, 137-145.

Veerasamy, R., Xin, T.Z., Gunasagaran, S., Xiang, T.F.W., Yang, E.F.C., Jeyakumar, N. Dhanaraj, S.A., 2011. Biosynthesis of silver nanoparticles using mangosteen lea extract and evaluation of their antimicrobial activities. J. Saudi Chem. Soc. 15 113-120.

Wang, Y., Herron, N., 1991. Nanometer-sized semiconductor clusters: materials synthesis, quantum size effects, and photophysical properties. J. Phys. Chem. 95, 525-532.

Zhou, D., Shao, L., Spitz, D.R., 2014. Reactive oxygen species in normal and tumour stem cells. Adv. Cancer Res. 122, 1-67.

Zhu, J., Liu, S., Palchik, O., Koltypin, Y., Gedanken, A., 2000. Shape-controlled synthesis of silver nanoparticles by pulse sonoelectrochemical methods. Langmuir 16, 6396-6399. 